\title{
SARS-CoV-2 Infection: Modulator of Pulmonary Embolism Paradigm
}

\author{
Mohammad Suhail Akhter ${ }^{1}$, Hassan A. Hamali ${ }^{1}$, Abdullah A. Mobarki ${ }^{1}$, Hina Rashid ${ }^{2}$, Johannes Oldenburg ${ }^{3}$ (D) \\ and Arijit Biswas ${ }^{3, *(1)}$ \\ 1 Department of Medical Laboratory Technology, Faculty of Applied Medical Sciences, Jazan University, \\ Jazan 45142, Saudi Arabia; makhter@jazanu.edu.sa (M.S.A.); hhamali@jazanu.edu.sa (H.A.H.); \\ abMobarki@jazanu.edu.sa (A.A.M.) \\ 2 Department of Pharmacology and Toxicology, College of Pharmacy, Jazan University, \\ Jazan 45142, Saudi Arabia; hzehqeer@jazanu.edu.sa \\ 3 Institute of Experimental Haematology and Transfusion Medicine, University Clinic Bonn, \\ 53127 Bonn, Germany; Johannes.Oldenburg@ukbonn.de \\ * Correspondence: Arijit.Biswas@ukbonn.de; Tel.: +49-22828719428
}

Citation: Akhter, M.S.; Hamali, H.A.; Mobarki, A.A.; Rashid, H.;

Oldenburg, J.; Biswas, A.

SARS-CoV-2 Infection: Modulator of Pulmonary Embolism Paradigm.

J. Clin. Med. 2021, 10, 1064. https://

doi.org/10.3390/jcm10051064

Academic Editor:

Laurence Panicot-Dubois

Received: 29 December 2020

Accepted: 24 February 2021

Published: 4 March 2021

Publisher's Note: MDPI stays neutral with regard to jurisdictional claims in published maps and institutional affiliations.

\begin{abstract}
Pulmonary embolism (PE) is a life-threatening complication arising from venous thromboembolism with a difficult diagnosis and treatment and is often associated with increased mortality and morbidity. PE had a significantly low incidence prior to the COVID-19 epidemic. This condition saw a sharp surge during the COVID-19 pandemic, indicating an evident viral influence on PE's pathophysiology in COVID-19 patients. The hypercoagulable state induced by the viral load seems to be the major contributor, and the classical causative factors seem to play a lesser role. PE in COVID-19 infection has become a mammoth challenge since the diagnosis is quite challenging due to overlapping symptoms, lack of prior-known predisposing risk factors, limited resources, and viral transmittance risk. Numerous factors arising out of the viral load or treatment lead to an increased risk for PE in COVID-19 patients, besides the fact that certain unknown risk factors may also contribute to the incidence of PE in COVID-19 patients. The management of PE in COVID-19 infection mainly comprises thromboprophylaxis and anticoagulant therapy with mechanical ventilation, depending on the risk stratification of the patient, with a post-COVID-19 management that prevents recurrent $\mathrm{PE}$ and complications. This review aims to discuss various aspects of COVID-19-infection-associated $\mathrm{PE}$ and major differential aspects from non-COVID-19 PE.
\end{abstract}

Keywords: COVID-19; pulmonary embolism; inflammation; thrombosis

\section{Introduction}

Pulmonary embolism (PE) is the more serious clinical presentation of venous thromboembolism (VTE). It is a prevalent condition that may cause hemodynamic compromise, resulting in significant morbidity and mortality [1]. The pathophysiological events involve the obstruction of the pulmonary vasculature caused by the lodging of emboli in the pulmonary arteries. Although endogenous lysis leads to dissolution of most of the small and moderate emboli, some emboli resist lysis and persist, subsequently obturating one or more vessels. A large embolus can obstruct the pulmonary vasculature to the extent where it increases strain on the right heart, leading to hypotension and death [2]. PE is the third most common cause of cardiovascular death worldwide after stroke and heart attack [3]. PE used to be a terminal event before advances in diagnostics and treatment, and the diagnosis and management of PE is still a challenge with its multitude of symptoms and increasing number of underlying medical conditions as potential risks [4]. The treatment outcome is largely determined by the patient hemodynamic status and right ventricular overload. A clinical presentation suspected of PE requires an expeditious diagnosis and treatment to decrease the mortality and morbidity [5]. While the most common origin of 
thrombus in PE has been identified as emboli from proximal leg or pelvic vein thromboses, numerous conditions associated with immunocompromised patients and those with comorbidities can trigger its onset [2]. Factors that increase hypercoagulability and/or lead to immobilization are the most common established risk factors for PE. Acute infection is also an associated risk factor for PE in both hospitalized and nonhospitalized patients and has been recognized as a potent risk factor independent of immobilization [4]. Although infection is a sporadic cause of PE, the strike of the COVID-19 pandemic since December 2019 has resulted in PE being a more serious consequence as result of the severe acute respiratory syndrome coronavirus 2 (SARS-CoV-2) infection [6]. Although COVID-19 has posed a challenge in the form of the high incidence of multiorgan involvement in comparison with other viral infections, the respiratory system is one of the most commonly involved organs. [7]. The virus exaggerates the inflammatory response and can lead to severe manifestations, such as adult respiratory syndrome, sepsis, coagulopathy, and death in a proportion of patients. Although a large proportion of patients present mild symptoms, a significant proportion can progress to severe complications, such as renal and cardiac injury, disseminated intravascular coagulation, or sepsis, leading to organ failure and death $[7,8]$. SARS-CoV-2 infection could increase predisposition to venous and arterial thromboembolism as a result of excessive inflammation, hypoxia, immobilization, and diffuse intravascular coagulation [9]. Cui et al. (2020) reported the prevalence of VTE to be $25 \%$ [10]. Increasing data from clinical and autoptic findings the world over strongly indicate an association of COVID-19 pneumonia with massive pulmonary microembolism and pulmonary infarction as a result of a wide thrombotic response to the infection. Development of PE in COVID-19 patients is a challenging situation since the patient is in delicate equilibrium and has an already high risk of thrombosis due to other predisposing factors for thromboembolism, such as hospitalization, immobility, and corticosteroid therapy [11]. PE in COVID-19 patients seems characteristically different from PE in non-COVID-19 patients, which heightens the challenges in treatment and management. In this review, we aim to discuss the differential aspects of PE resulting from SARS-CoV-2 infection as against $\mathrm{PE}$ in non-COVID-19 patients and the various challenges posed by $\mathrm{PE}$ in the context of COVID-19.

\section{Incidence}

Prior to the strike of COVID-19, the overall annual incidence of PE was estimated to be 0.6 per 1000 . It was, however, anticipated that the occurrence is higher since only $40 \%-50 \%$ of premortem cases were diagnosed for PE [12,13]. With the onset of COVID-19, a marked increase, about more than double, in the incidence of PE the world over has been observed [14]. COVID-19 infection has PE as the most common manifestation, with inhospital incidence being higher in ICU patients compared with those hospitalized in general wards $[9,15]$. The incidence of $\mathrm{PE}$ has been mostly reported by sparse retrospective cohort studies that may have underestimated the incidence owing to a lack of methodical screening for this complication. Observational data suggest that $7 \%-39 \%$ of patients with COVID-19 infection who require mechanical ventilation have acute PE or deep vein thrombosis (DVT), and the probability of developing PE is moderate to high in those with symptoms of DVT [16]. In a Chinese study, Miesbach et al. (2020) reported that up to $40 \%$ of the patients developed PE chiefly localized in small branches of the pulmonary artery [17]. In a French study, Poissy et al. (2020) reported PE in 20.6\% of the patients during their stay in the ICU, with a median time of ICU admission of 6 days [18]. In a French study, a twofold increase in the incidence of PE was observed in patients hospitalized in the ICU during the same time interval in 2019, with a similar severity score. Hauguel-Moreau et al. (2020) compared the incidence of PE during a 3-year period from January 2017 to April 2020 and observed a $97.4 \%$ increase of PE incidence as compared with that from 2017 to 2019 [19]. Another study by Bompard et al. (2020) in a French population reported a PE incidence of $50 \%$ in ICU patients, $18 \%$ in other patients, and an overall $24 \%$ cumulative incidence in patients with COVID-19 pneumonia [20]. In a Spanish study, Mestre-Gómez 
et al. (2020) reported the cumulative incidence of PE to be $6.4 \%$ in COVID-19 patients [21]. Benito et al. (2020) reported a 2.6\% incidence of PE in COVID-19 hospitalized patients in a Spanish study [22] (Table 1). Liao et al. (2020) reported that, overall, 15.3\% of COVID-19 patients developed PE, and the incidence of PE in COVID-19 patients was higher by $3 \%$ than that in patients with seasonal and pandemic influenza [23]. Piroth et al. (2020), in their nationwide retrospective cohort study in France, found that the rate of PE was clearly higher in COVID-19 (3.4\%) than in 2018-2019 seasonal influenza (0.9\%) [24]. Data from numerous meta-analyses also strongly indicate a higher incidence of PE in COVID-19 patients, especially in ICU settings. Jiménez et al. (2020), in their meta-analyses that included a pooled sample of 18,093 patients, reported an overall pooled incidence of PE of 7.1\% in COVID-19 patients [25]. Zhang et al. (2020), in their meta-analysis of 40 clinical studies that involved 7966 patients hospitalized with COVID-19, reported the pooled prevalence of VTE, PE, and DVT for consecutive hospitalized patients to be $13 \%$, $8 \%$, and $7 \%$, respectively. ICU patients had a pooled VTE prevalence of $31 \%$, which was significantly higher than non-ICU patients (prevalence of 7\%). Compared with non-ICU patients, ICU patients also had a threefold higher pooled prevalence of PE (17\% vs. $4 \%)$ and DVT ( $25 \%$ vs. $7 \%$ ) [26]. Meta-analysis involving 27 studies with 3342 patients with COVID-19 by Suh et al. (2020) reported pooled incidence rates of PE and DVT of $16.5 \%$ and $14.8 \%$, respectively. PE was more frequent in patients admitted to the ICU than those not admitted to the ICU $(24.7 \%$ vs. $10.5 \%)[27,28]$. Boonyawat et al. $(2020)$, in their metaanalysis to demonstrate the pooled incidence of venous and arterial thromboembolism in COVID-19 patients in various settings, reported a pooled incidence of VTE of $28 \%$ and $10 \%$ in ICU and non-ICU settings, respectively [29]. All these studies indicate SARS-CoV-2 infection as a factor for a sudden surge in the incidence of PE the world over.

Table 1. Incidence and mortality of PE in COVID-19 patients.

\begin{tabular}{|c|c|c|c|c|c|c|c|c|c|}
\hline & Author & $\begin{array}{l}\text { Study } \\
\text { Design }\end{array}$ & $\begin{array}{c}\text { Mean Age } \\
\text { (Years) }\end{array}$ & $\begin{array}{l}\text { Number of } \\
\text { Patients }\end{array}$ & $\begin{array}{c}P E \\
\text { Incidence } \\
(\%)\end{array}$ & ICU (\%) & $\begin{array}{l}\text { Mortality } \\
(\%)\end{array}$ & Thromboprophylaxis & PE Imaging Test \\
\hline 1 & $\begin{array}{l}\text { Artifoni } \\
\text { et al. [30] }\end{array}$ & $\begin{array}{l}\text { Retrospective } \\
\text { cohort } \\
\text { double- } \\
\text { center } \\
\text { study }\end{array}$ & 64 & 133 & 10 & 12.78 & 14.28 & Heparin (unspecified) & $\begin{array}{l}\text { Low limb venous duplex } \\
\text { ultrasonography/CTPA * }\end{array}$ \\
\hline 2 & $\begin{array}{l}\text { Lodigiani } \\
\text { et al. [31] }\end{array}$ & $\begin{array}{l}\text { Retrospective } \\
\text { single-center }\end{array}$ & 66 & 388 & 2.8 & 16 & 26 & $\begin{array}{l}\text { Low-molecular-weight } \\
\text { heparin }\end{array}$ & $\begin{array}{l}\text { Two-point compression } \\
\text { ultrasonography }\end{array}$ \\
\hline 3 & $\begin{array}{l}\text { Poissy } \\
\text { et al. [18] }\end{array}$ & $\begin{array}{l}\text { Retrospective } \\
\text { single-center }\end{array}$ & 57 & 107 & 20.6 & 20.6 & 14 & $\begin{array}{c}\text { Unfractionated heparin or } \\
\text { low-molecular-weight } \\
\text { heparin }\end{array}$ & CTPA \\
\hline 4 & $\begin{array}{l}\text { Grillet } \\
\text { et al. [32] }\end{array}$ & $\begin{array}{l}\text { Retrospective } \\
\text { single-center }\end{array}$ & 66 & 100 & 23 & 39 & NR & NR & CTPA \\
\hline 5 & $\begin{array}{l}\text { Leonard- } \\
\text { Lorant } \\
\text { et al. [33] }\end{array}$ & $\begin{array}{l}\text { Retrospective } \\
\text { double- } \\
\text { center }\end{array}$ & 63.5 & 106 & 30.2 & 75 & NR & $\begin{array}{l}\text { Low-molecular-weight } \\
\text { heparin }\end{array}$ & CTPA \\
\hline 6 & $\begin{array}{l}\text { Llitjos } \\
\text { et al. [34] }\end{array}$ & $\begin{array}{l}\text { Retrospective } \\
\text { double- } \\
\text { center }\end{array}$ & 68 & 26 & 23.1 & $\begin{array}{l}\text { An ICU } \\
\text { study }\end{array}$ & 12 & $\begin{array}{c}\text { Low-molecular-weight } \\
\text { heparin or unfractionated } \\
\text { heparin }\end{array}$ & $\begin{array}{l}\text { Complete duplex } \\
\text { ultrasound }\end{array}$ \\
\hline 7 & $\begin{array}{l}\text { Klok et al. } \\
{[9]}\end{array}$ & $\begin{array}{l}\text { Retrospective } \\
\text { multicenter }\end{array}$ & 64 & 184 & 35.5 & $\begin{array}{l}\text { An ICU } \\
\text { study }\end{array}$ & 22 & $\begin{array}{c}\text { Low-molecular-weight } \\
\text { heparins } \\
\text { Unfractionated }\end{array}$ & $\begin{array}{l}\text { CTPA and/or } \\
\text { ultrasonography }\end{array}$ \\
\hline 8 & $\begin{array}{l}\text { Thomas } \\
\text { et al. [35] }\end{array}$ & $\begin{array}{l}\text { Retrospective } \\
\text { single-center }\end{array}$ & 59 & 63 & 7.9 & $\begin{array}{l}\text { An } \\
\text { ICUs- } \\
\text { tudy }\end{array}$ & 16 & $\begin{array}{c}\text { heparin/low-molecular- } \\
\text { weight } \\
\text { heparin }\end{array}$ & $\begin{array}{l}\text { Lower limb ultrasound } \\
\text { dopplers/CTPA }\end{array}$ \\
\hline 9 & $\begin{array}{l}\text { Middeldorp } \\
\text { et al. [36] }\end{array}$ & $\begin{array}{l}\text { Retrospective } \\
\text { single-center }\end{array}$ & 61 & 198 & 6.6 & 38 & 19 & $\begin{array}{c}\text { Low-molecular-weight } \\
\text { heparin } \\
\text { Unfractionated }\end{array}$ & CTPA \\
\hline 10 & $\begin{array}{l}\text { Helms } \\
\text { et al. [37] }\end{array}$ & $\begin{array}{l}\text { Prospective } \\
\text { multicenter }\end{array}$ & 63 & 150 & 16.7 & $\begin{array}{l}\text { An ICU } \\
\text { study }\end{array}$ & 9 & $\begin{array}{c}\text { heparin/low-molecular- } \\
\text { weight } \\
\text { heparin }\end{array}$ & $\begin{array}{c}\text { CTPA/abdomen and } \\
\text { pelvis CT }\end{array}$ \\
\hline 11 & $\begin{array}{l}\text { Hékimian } \\
\text { et al. [38] }\end{array}$ & $\begin{array}{l}\text { Retrospective } \\
\text { single-center }\end{array}$ & NA & 51 & 16 & $\begin{array}{l}\text { An ICU } \\
\text { study }\end{array}$ & NR & NR & СТPA \\
\hline 12 & $\begin{array}{c}\text { Galeano- } \\
\text { Valle et al. } \\
\text { [39] }\end{array}$ & $\begin{array}{l}\text { Prospective } \\
\text { observa- } \\
\text { tional } \\
\text { single-center }\end{array}$ & 64.3 & 24 & 45.8 & 3 & NR & NR & CTPA \\
\hline
\end{tabular}


Table 1. Cont.

\begin{tabular}{|c|c|c|c|c|c|c|c|c|c|}
\hline & Author & $\begin{array}{l}\text { Study } \\
\text { Design }\end{array}$ & $\begin{array}{l}\text { Mean Age } \\
\text { (Years) }\end{array}$ & $\begin{array}{l}\text { Number of } \\
\text { Patients }\end{array}$ & $\underset{\substack{P E \\
\text { Incidence } \\
(\%)}}{ }$ & ICU (\%) & $\underset{(\%)}{\text { Mortality }}$ & Thromboprophylaxis & PE Imaging Test \\
\hline 13 & $\begin{array}{l}\text { Bompard } \\
\text { et al. [20] }\end{array}$ & $\begin{array}{l}\text { Retrospective } \\
\text { double- } \\
\text { center }\end{array}$ & 64 & 135 & 23.7 & 17 & 12 & Heparin (unspecified) & CTPA \\
\hline 14 & $\begin{array}{l}\text { Soumagne } \\
\text { et al. [40] }\end{array}$ & $\begin{array}{l}\text { Retrospective } \\
\text { multicenter }\end{array}$ & 63.5 & 375 & 15 & $\begin{array}{l}\text { An ICU } \\
\text { study }\end{array}$ & NR & $\begin{array}{l}\text { Anticoagulant not } \\
\text { specified }\end{array}$ & NR \\
\hline 15 & $\begin{array}{l}\text { Fraissé } \\
\text { et al. [41] }\end{array}$ & $\begin{array}{l}\text { Retrospective } \\
\text { single-center }\end{array}$ & 61 & 93 & 49 & $\begin{array}{l}\text { An ICU } \\
\text { study }\end{array}$ & 41 & $\begin{array}{l}\text { Anticoagulant not } \\
\text { specified }\end{array}$ & NR \\
\hline 16 & $\begin{array}{l}\text { Freund } \\
\text { et al. [42] }\end{array}$ & $\begin{array}{l}\text { Retrospective } \\
\text { multicenter }\end{array}$ & 61. & 3253 & 15 & 0 & NR & NR & CTPA \\
\hline 17 & $\begin{array}{l}\text { Chen et al. } \\
\text { [43] }\end{array}$ & $\begin{array}{l}\text { Retrospective } \\
\text { single-center }\end{array}$ & 65 & 25 & 40 & NR & 24 & NR & СТPA \\
\hline 18 & $\begin{array}{l}\text { Longchamp } \\
\text { et al. [44] }\end{array}$ & $\begin{array}{l}\text { Retrospective } \\
\text { single-center }\end{array}$ & 68 & 25 & 20.0 & $\begin{array}{l}\text { An ICU } \\
\text { study }\end{array}$ & 20 & Heparin (unspecified) & CTPA/CUS ** \\
\hline 19 & $\begin{array}{l}\text { Whyte } \\
\text { et al. [45] }\end{array}$ & $\begin{array}{l}\text { Retrospective } \\
\text { single-center }\end{array}$ & 61.5 & 1477 & 37 & 15 & 16 & $\begin{array}{c}\text { Unfractionated } \\
\text { heparin/low-molecular- } \\
\text { weight } \\
\text { heparin }\end{array}$ & CTPA \\
\hline 20 & $\begin{array}{l}\text { Marone } \\
\text { et al. [46] }\end{array}$ & $\begin{array}{l}\text { Retrospective } \\
\text { single-center }\end{array}$ & NA & 101 & 23.7 & NR & NR & $\begin{array}{c}\text { Low-molecular-weight } \\
\text { heparin } \\
\text { Unfractionated }\end{array}$ & Duplex ultrasound/CTPA \\
\hline 21 & $\begin{array}{l}\text { Fauvel } \\
\text { et al. [47] }\end{array}$ & $\begin{array}{l}\text { Retrospective } \\
\text { multicenter }\end{array}$ & 64 & 1240 & 8.3 & 14.9 & 12.2 & $\begin{array}{c}\text { heparin/low-molecular- } \\
\text { weight } \\
\text { heparin }\end{array}$ & CTPA \\
\hline 22 & $\begin{array}{l}\text { Van den } \\
\text { Heuvel } \\
\text { et al. [48] }\end{array}$ & $\begin{array}{l}\text { Retrospective } \\
\text { single-center }\end{array}$ & 63 & 51 & 18 & 37 & 1 & NR & СТРА \\
\hline 23 & $\begin{array}{l}\text { Mestre- } \\
\text { Gómez } \\
\text { et al. [21] }\end{array}$ & $\begin{array}{l}\text { Retrospective } \\
\text { single-center }\end{array}$ & 65 & 29 & 6.4 & 6.9 & 3.4 & $\begin{array}{l}\text { Low-molecular-weight } \\
\text { heparin }\end{array}$ & СТРА \\
\hline 24 & $\begin{array}{l}\text { Faggiano } \\
\text { et al. [49] }\end{array}$ & $\begin{array}{l}\text { Retrospective } \\
\text { single-center }\end{array}$ & 70.3 & 25 & 7 & NR & 14 & $\begin{array}{c}\text { Unfractionated or } \\
\text { low-molecular-weight } \\
\text { heparin }\end{array}$ & СТРA \\
\hline 25 & $\begin{array}{l}\text { Gervaise } \\
\text { et al. [50] }\end{array}$ & $\begin{array}{l}\text { Retrospective } \\
\text { single-center }\end{array}$ & 62.3 & 72 & 18 & 57 & 15 & NR & СТPA \\
\hline 26 & $\begin{array}{l}\text { Trimaille } \\
\text { et al. [51] }\end{array}$ & $\begin{array}{l}\text { Retrospective } \\
\text { single-center }\end{array}$ & 62.2 & 289 & 14.5 & 72 & 47 & $\begin{array}{c}\text { Unfractionated } \\
\text { heparin/low-molecular- } \\
\text { weight } \\
\text { heparin }\end{array}$ & СТРА \\
\hline
\end{tabular}

* CTPA—Computed tomography pulmonary angiogram; ${ }^{* *}$ CUS—Compression ultrasound.

To date (January 2021), a total of over 100 million cases have been reported all over the world from the start of the outbreak, and the admission rate to the ICU varies from $3 \%$ to $100 \%$ [52]. This is highly denotive of a sharp upsurge in the incidence of PE the world over with COVID-19 infection being an imponderable factor. However, a precise rate of incidence of PE in COVID-19 still requires meticulous evaluation since interpretations may be affected by the nature, sensitivity, and specificity of the studies carried out to explore the incidence [23]. Another factor that may mask the exact incidence is the lack of reporting of PE from all the nations, especially the densely populated ones and the ones that were the epicenters. Additionally, an anticipated second wave of the pandemic, by now in a few parts of the world, will also determine the incidence of PE in COVID-19 patients. This sudden upsurge in the incidence of PE has placed a tremendous burden on the health care systems worldwide, and their unpreparedness has led to high mortality from COVID-19, despite lower case fatality rate [47].

\section{Risk Factors}

The risk factors for PE in COVID-19 patients differ from traditional thromboembolic risk factors. Numerous studies have reported them to be independent clinico-biological parameters, which are mostly driven by inflammation and coagulopathy [53,54]. The factors that have been identified as risk factors for PE in COVID-19 patients are male gender, history of stroke or atrial fibrillation, chest pain, and dyspnea. The presence of systemic inflammation, higher D-dimer level, elevated C-reactive protein level, rising D-dimer value over time, high fraction of inspired oxygen, and severe pulmonary lesions in computed tomography scan is also associated with a higher risk of PE. Another noteworthy feature is that patients with PE show extended delay from onset of symptoms to hospitalization compared with patients without PE $[30,53]$. The well-known conventional risk factors of thromboembolism, such as fracture of the lower limb, hospitalization for heart failure or 
atrial fibrillation/flutter, hip or knee replacement, major trauma, myocardial infarction, spinal cord injury, postpartum period, and obesity, did not seem to be risk factors for PE in most studies, although they may still have some relevance [30,55]. Poyiadji et al. (2020), however, reported that African Americans and obese patients are more likely to develop PE [56]. No strong association has been found between a higher risk of PE and cardiovascular comorbidities, such as diabetes, hypertension, chronic heart failure, and coronary artery disease, in various studies [53]. Certain therapeutic interventions used for the treatment of infection may also act as risk factors, if not prescribed with caution. The convalescent plasma therapy used as a treatment for COVID-19 infection in many settings itself can pose a risk since it contains procoagulant factors and can trigger PE as the patient is already having an increased prothrombotic state [57]. The necessity for mechanical ventilation in some patients can also act as a strong risk for developing PE in COVID-19 patients [32]. In most of the cases of refractory respiratory dysfunction in COVID-19, veno-venous extracorporeal membrane oxygenation (ECMO) may represent an efficient life-saving rescue therapy; however, this amplifies the risk for PE [58]. ECMO leads to systemic activation of coagulation and inflammation pathways that result from the large and continuous contact surface between the humoral and cellular components of the blood and the extracorporeal circuit, leading to increased chance of PE [59]. This can be correlated to the observational data that show that $7 \%-39 \%$ of patients with COVID-19 infection requiring mechanical ventilation have acute PE/DVT [16]. Since no major conventional predisposing risk factors for PE have been found to be associated with the incidence of PE in COVID-19 in most of the studies; it may indicate mild to moderate COVID-19 infections to instigate PE. This may predict of COVID-19 being an independent risk factor for PE; however, this needs validation studies [54]. The absence of conventional predicting factors for PE results in a strenuous diagnosis. This often leads to underreporting, especially with an exponentially growing number of patients and in low economic settings.

\section{Virus-Inflected Pathophysiology}

Most often, non-COVID-19-associated PE has thrombus of the lower extremities, especially the calf veins, as its origin. The thrombus sets about due to decreased blood flow and propagates because of local hypercoagulability resulting from hypoxia and hemoconcentration. A smaller percentage of emboli are developed from upper extremity veins and may have provoking risk factors as contributors. The thrombus travels from the point of origin and lodges in the pulmonary arterial system, passing through the systemic venous system and the right-sided chambers of the heart $[2,60]$. While an acute minor PE may not cause any serious symptoms, acute major PE reduces the cardiac output and is often fatal [57]. While PE has been reported to occur in other viral pneumonias also, the frequency is lesser compared with that in COVID-19 patients [20]. This indicates a varied pathophysiology that is modulated by the virus. It has been postulated that a unique local thrombus formation occurs primarily in the lungs because of the inflammatory process rather than emboli developing in other body parts in COVID-19-associated PE [61]. Although the exact pathophysiology of PE in COVID-19 needs validation, it is suspected to be multifactorial, being more platelet dependent, mostly associated with virus-mediated endothelial injury, and with angiotensin-converting enzyme-2 (ACE2) having a pivotal role.

The role of platelets in the pathophysiology of COVID-19-associated PE is being explored widely. This is in view of earlier sufficient studies demonstrating that viruses can directly interact with platelets and modulate their thrombotic and inflammatory functions. Accumulating data indicate an important role of platelets in COVID-19-associated thrombosis. Platelets may take up SARS-COV-2 mRNA independent of ACE2 during SARS-CoV-2 infection, while endothelial damage in COVID-19 disease may release important platelet agonists that cause overactivation of platelets $[62,63]$. The platelets in COVID-19 patients are reported to be hyperreactive and show increased aggregation, adhesion, and spreading on both fibrinogen and collagen. This increased platelet activation and aggregation may be partly due to increased MAPK pathway activation and thromboxane generation. 
Increase in the markers of platelet activation, such as P-selectin, CD63, and soluble CD40L, in COVID-19 patients is well reported. A significant increase in von Willebrand factor (VWF) in COVID-19 patients indicates a tendency towards platelet plug formation and thrombosis $[64,65]$. Once activated, the platelets form aggregates with neutrophils, which are frequently seen in thromboinflammation and are reported to be elevated in COVID-19 patients. Interaction between activated platelets and neutrophils also leads to the formation of neutrophil extracellular traps (NETs), which can lead to thrombus formation in lung microcirculation. Significantly increased NETs have been observed in the blood and pulmonary capillaries of COVID-19 patients, further strengthening the role of platelets in COVID-19-induced thrombosis [66,67]. In acutely ill COVID-19 patients, platelets may show a significant change in gene expression in pathways associated with protein ubiquitination, antigen presentation, and mitochondrial dysfunction. Such data indicate that platelet gene expression is altered, and functional responses are significantly increased during SARS-CoV-2 infection, which may contribute to thrombotic events in COVID-19 patients [62].

Endothelial injury may also be a major contributor to the pathogenesis of PE in COVID19 patients. Currently, it is postulated that SARS-CoV-2 enters target cells through ACE2 by receptor-mediated endocytosis; however, other receptors, such as CD209L (L-SIGN), CD209 (DC-SIGN), neuropilin receptors, and CD147/basigin, may also facilitate the SARS-CoV-2 entry [68]. ARS-CoV-2 has a 10- to 20-fold increased binding affinity to ACE2 compared with SARS-CoV-1, and this high affinity may account for the increased pathogenicity of the virus [69]. ACE2 is well expressed in endothelial cells in the lungs (Figure 1), and the virus invasion may have an impact on the lung circulation through the renin-angiotensin system. Once ACE2 binds to SARS-CoV-2, it is internalized and downregulated on endothelial cells. This downregulation of ACE2 may result from ADAM-17/TACE activation by the SARS spike protein, which cleaves and releases ACE2, and/or the endocytosis of the ligand/receptor complex, followed by subsequent intracellular degradation. The degradation promotes proinflammatory and prothrombotic processes in the lung triggered by local angiotensin II (Ang II) hyperactivity [70]. Given that ACE2 is an enzyme involved in the renin-angiotensin-aldosterone system pathway, it converts Ang II into Ang (1-7), which acts on the MAS receptor. It can be perceived that a decreased ACE2 expression by endothelial cells in response to SARS-CoV-2 infection decreases the generation of Ang (1-7), which subsequently reduces the activation of MAS, consequently promoting a local prothrombotic state in endothelial cells. A downregulated ACE2 expression might also indirectly activate the kallikrein-kinin system (KKS), which leads to increases in vascular permeability $[63,71]$. A precise balance between the KKS and renin-angiotensin systems is necessary to regulate the thromboresistance of endothelial cells, and any disruption can have adverse outcomes [72,73].

Another major pathological mechanism that was considered crucial for PE in COVID19 patients is "cytokine storm"; however, numerous recent studies seem to question its relevance $[74,75]$. The lung cells, in response to SARS-CoV-2 infection, generate proinflammatory cytokines and chemokines, attracting immune cells at the spot and further promoting inflammation and establishing a proinflammatory feedback loop. A defective immune system can lead to an overproduction of proinflammatory cytokines, causing a significant damage to the lung structure. This can cause a sustained inflammatory response, resulting in cytokine storm [76,77]. The cytokine storm involves the release of elevated plasma levels of proinflammatory cytokines, such as interleukin (IL)-2, IL-6, IL-7, IL-8, interferon gamma-induced protein 10, monocyte chemotactic protein-1, granulocyte colonystimulating factor, macrophage inflammatory protein $1 \mathrm{a}$, and tumor necrosis factor [78]. This storm leads to the development of hemophagocytic lymphohistiocytosis and activates the blood coagulation system [79]. This increases the risk of intravascular microthrombosis and secondary local consumption coagulopathy [80]. This is validated by the presence of platelet-fibrin thrombi in the small arterial vessels in lung necropsies [81]. Additionally, in an attempt to clear the viral load, white blood cell activation and clot formation 
increase the procoagulant state and may contribute to PE [82]. The fact that coagulation and inflammatory pathways are intricately coupled to each other has major implications for PE in COVID-19. Several hypotheses currently exist regarding the role of coagulation protein in the PE-related phenotype of COVID-19. Von Willebrand factor, an acute-phase coagulation protein, has been shown to be 5- to 10-fold elevated in symptomatic COVID-19 patients [83]. As a result, the protease ADAMTS13, which is the downregulator (through cleavage) of VWF in blood, becomes relatively deficient owing to overconsumption. This relative deficiency of ADAMTS13 can result in an altered VWF multimer pattern with larger VWF multimers which may affect the microvascular circulation in the capillaries of organs including the lung. The larger VWF multimers also can serve as an activating surface for amplification of complement pathways. VWF is also known as a risk factor for macrovascular thrombosis. VWF can have an indirect effect on thrombosis mediated by coagulation factor VIII (FVIII), since VWF is the carrier protein for FVIII and FVIII activity is dependent on VWF levels. FVIII is a strong acute-phase protein. FVIII activities are increased four to six times in COVID-19 patients [83]. Raised FVIII/VWF levels of $>150 \%$ are known to be significant risk factors for thrombosis [84]. Hyperactivation of FVIII can result in a thrombin burst, creating a prothrombotic scenario. FVIII is downregulated by the activated protein C (APC) system. Excessive FVIII activity may exhaust the APC system and result in a very significant risk for thrombosis in macrovascular circulation and thus contribute to the high incidence of primary lung embolism in patients with COVID-19 disease. Another critical point to consider when talking about the links between COVID-19, coagulation, and $\mathrm{PE}$ is the $\mathrm{ABO}$ blood group [85]. The $\mathrm{ABO}$ blood group has a significant influence on VWF and FVIII activity. The blood groups $\mathrm{O}$ and $\mathrm{A} 2$ have been shown to have 50\% lower VWF and FVIII activity than blood groups A1, B, A1B, and A2B [86]. Therefore, they might have a secondary but indirect effect on COVID-19 pathophysiology mediated by VWF and FVIII. The heterogeneity and overlapping in the mechanisms of PE in COVID-19 may pose a challenge in defining a line of treatment and further management to reduce complications especially when choosing the nature of complication. This is of significant concern since PE survivors have a higher risk of developing post-PE syndrome and recurrent PE and other functional impairments. However, more detailed investigations are needed to define the multiple ways in which COVID-19 manifests into a hypercoagulant pathophysiology in PE. 


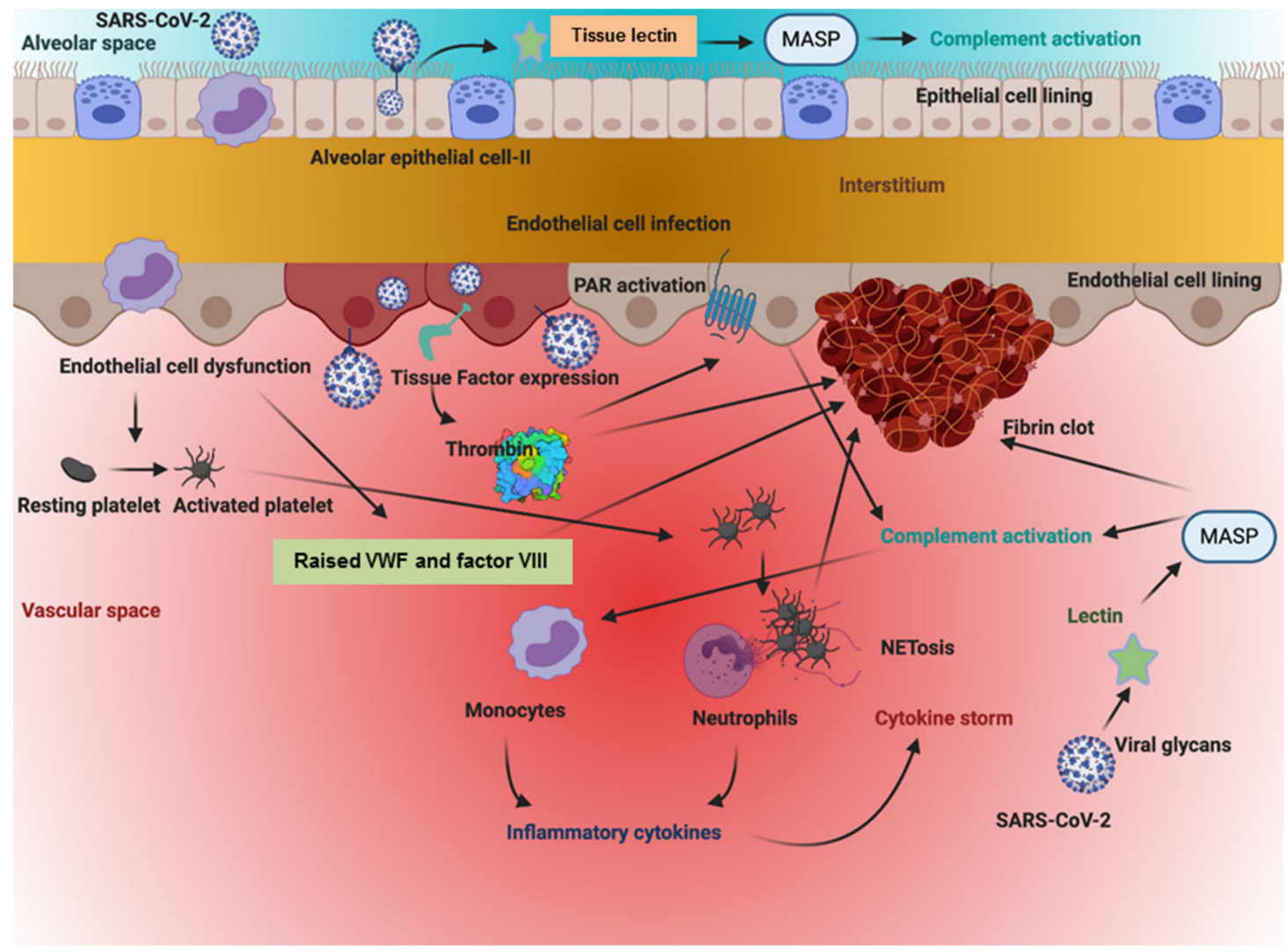

Figure 1. The above figure illustrates how the SARS-CoV-2 virus sets off a series of chain reactions in the intracellular and extracellular spaces of cells of the vasculature lining the alveolar space. This simultaneously sets into motion coagulation, inflammation, and complement-based pathways, resulting in a hypercoagulable state and a cytokine storm that worsens the clinical state of the individual. As is apparent from the figure, each pathway feeds into the enhancement of the other.

\section{Diagnosis}

Establishing a precise diagnosis of PE has often been challenging and quite difficult. This is because of the nonspecific symptoms of PE and/or the absence of any symptoms at all [87]. Pre-existing cardiac and pulmonary conditions further make the diagnosis difficult [60]. However, an early diagnosis is highly recommended to improve prognosis and requires an interdisciplinary approach to avoid misinterpretations. Although diagnostic strategies differ in various clinical settings, the diagnostic workup includes clinical probability assessment, followed by biomarker assessment and imaging. The Wells Clinical Prediction Rule is most commonly used to predict possibility and validates the clinical probability of low or intermediate risk and high risk [88]. A low or intermediate probability of PE needs D-dimer measurements, followed by an imaging test, while for a high probability of PE, imaging tests are mandatory [89]. Imaging tests predominantly have computed tomography pulmonary angiography (CTPA) as gold standard [90]. The diagnosis of COVID-19-infection-associated PE is further complicated, and an altered approach is rendered. Primarily, in COVID-19 patients, the signs and symptoms of acute respiratory distress syndrome and PE may overlap, escalating the diagnostic challenge. Secondly, other underlying conditions, such as pregnancy and cardiopulmonary comorbidities, further amplify the diagnostic difficulties. Another major hurdle in opportune diagnosis is strict isolation precautions that require minimum contact of health-care workers with the patient [90]. This has led to a change in the diagnostic approach to attain the best possible diagnosis with the least risk to the health-care staff and patient. A multidisciplinary approach is still indispensable but is more customized for patients. The physician evaluating COVID-19 patients should keenly estimate the progress of COVID-19 symptoms along with the risk 
factors for PE. Testing for PE should be prioritized if the patient exhibits hemodynamic instability or an unexplained poor gas exchange for the stage or presents with minimal pulmonary infiltrates or signs of acute right ventricular (RV) overload [91,92]. Studies from France suggest that PE occurred in COVID-19 patients at a median of 6 days [18]. As a marker for hemostasis, D-dimer testing has been followed almost the world over; however, necessitating D-dimer in diagnostic decision-making for PE has an overall varied response $[93,94]$. Normal levels of D-dimer have the ability to rule out PE, especially in the context of low pretest probability, and can annul radiological imaging. However, a false negative rate of D-dimer testing, although very rare, cannot be ruled out [16]. Elevated D-dimer $(>2.0 \mu \mathrm{g} / \mathrm{mL})$ levels have been associated with worst outcomes and increased mortality in COVID-19 patients all over the world [20]. Vidali et al. (2020), in their study to estimate D-dimer as an indicator of prognosis in SARS-CoV-2 infection, evaluated 16 studies and found 13 studies to have significantly increased D-dimer in COVID-19 patients compared with healthy controls. The dimer was also increased in COVID-19 patients with severe disease compared with those with nonsevere disease [95]. D-dimer level excludes very few patients from the need for a confirmatory imaging test. If the D-dimer levels change from normal to high or are rapidly increasing, then imaging is required. However, other factors that interfere with D-dimer levels, such as secondary infection, myocardial infarction, renal failure, and coagulopathy, also need to be screened [16]. The necessity of imaging, especially CTPA, in the detection of PE in COVID-19 patients presents one of the major challenges. The transfer of a patient to the CTPA suite increases the chances of disease transmission and calls for disinfection of the CT suite. The use of contrast media might be contraindicated in patients with severe COVID-19 with associated renal dysfunction or patients with contrast allergy [96]. Strict isolation measures because of the chances of virus aerosolization and the possibility of unavailability of personal protective equipment further limit CTPA in a pandemic setting. To overcome this limitation, it is highly recommended that bedside echocardiogram and lower-extremity ultrasonography be the preferred modalities [92]. Echocardiography remains the first-line imaging modality for early detection of PE in the assessment of the critically ill. Echocardiography provides some valuable diagnostic information, such as noninvasive estimation of cardiac output, diastolic function parameters, and evaluation of right ventricular function and pulmonary circulation, which is highly valuable in patients that have severe hypoxemia and require mechanical ventilation. All these parameters are helpful in treating critically ill COVID-19 patients, especially as regards optimizing positive end-expiratory pressure and the possibility of successful weaning from mechanical ventilation [97]. When carried out, balancing the benefits and risks of disease transmission, echocardiography findings can lead to a treatment change in up to $33 \%$ of such patients [98]. Echocardiography can be particularly helpful in the management of selected COVID-19 patients, especially those with elevated Ddimer and troponin levels, and can be helpful in changing the treatment regime to improve the outcomes. Scudiero et al. (2020) reported an echocardiography-induced change in the treatment of $16 \%$ of the COVID-19 patients in their study. A higher systolic pulmonary arterial pressure and documented cardiac thrombi on echocardiography were associated with treatment changes in these patients. They observed significantly $(p=0.010)$ higher rates of mortality and cardiogenic shock in patients with PE as compared with non-PE patients. In their study, tricuspid annular plane systolic excursion and systolic pulmonary arterial pressure were the only parameters that were independently associated with the occurrence of PE in COVID-19 patients [99].

\section{Prophylactic and Therapeutic Interventions}

The fundamentals of therapy for PE in non-COVID-19 settings are the prevention of new embolic episodes by employing anticoagulant treatment or a filter in the inferior vena cava [100]. The treatment of PE in COVID-19 patients, however, deems both prophylactic and curative therapies to be vital, depending on the level of risk and the condition of the patient [92] (Table 2). While numerous guidelines have been issued by various bodies, 
the responsibility of health professionals to make appropriate decisions in the circumstances of individual patients remains prime. The International Society on Thrombosis and Haemostasis (ISTH) and the American Society of Hematology (ASH) recommend a prophylactic dose of LMWH (40 mg qd) or subcutaneous unfractionated heparin (5000 IU tid) for COVID-19 patients; however, the precise effective dose still needs to be determined with considerations for bleeding disorders $[17,101,102]$.

Table 2. Recommendations for treatment and follow-up for patients suspected of/confirmed for PE. [90,92].

\begin{tabular}{|c|c|c|}
\hline Condition of the Patient & Level of Risk for PE & Treatment \\
\hline Stable & Mild and moderate risk & $\begin{array}{l}\text { Pharmacological prevention is prescribed. LMWH is } \\
\text { recommended as first-line treatment, in the absence } \\
\text { of contraindication. }\end{array}$ \\
\hline Traumatic & Mild and moderate risk & $\begin{array}{l}\text { Pharmacological prevention is prescribed. LMWH is } \\
\text { recommended as first-line treatment, in the absence of } \\
\text { contraindication. } \\
\text { In case of contraindication for pharmacological } \\
\text { thromboprophylaxis, mechanical thromboprophylaxis } \\
\text { is preferred. }\end{array}$ \\
\hline Stable (discharged) & Persistent mild and moderate risk & $\begin{array}{l}\text { Prolonged outpatient } \mathrm{VTE}^{*} \text { prophylaxis care is } \\
\text { considered with } \mathrm{LMWH} \mathrm{H}^{* *} \text { over DOAC } \\
\text { prevent drug-drug interactions, and/or to } \\
\text { frequent comorbidities. }\end{array}$ \\
\hline Acute & Confirmed & $\begin{array}{l}\text { Initial parenteral anticoagulation with LMWH or UFH, } \\
\text { overlapped with latter vitamin K antagonist therapy. }\end{array}$ \\
\hline Shock/hypotension & Confirmed & $\begin{array}{l}\text { Systemically administered thrombolytics if there is no } \\
\text { high risk of bleeding. }\end{array}$ \\
\hline $\begin{array}{l}\text { Acute/cardiopulmonary } \\
\text { deterioration }\end{array}$ & Confirmed & $\begin{array}{l}\text { Systemic thrombolytic therapy after an initiation of } \\
\text { anticoagulant therapy in the absence of hypotension and } \\
\text { a low risk of bleeding. }\end{array}$ \\
\hline Acute & Confirmed & $\begin{array}{l}\text { Systemic thrombolysis for patients eligible for advanced } \\
\text { therapy but lack an invasive approach due to limited } \\
\text { resources or high risk of viral transmission. }\end{array}$ \\
\hline $\begin{array}{l}\text { Critical (refractory circulatory } \\
\text { collapse or cardiac arrest) }\end{array}$ & Confirmed & $\begin{array}{l}\text { ECMO } * * * * \text { in combination with surgical embolectomy } \\
\text { or catheter-directed treatment. }\end{array}$ \\
\hline Stable (outpatient) & Confirmed & $\begin{array}{l}\text { Parenteral anticoagulants overlapped with vitamin } \\
\text { K antagonists. }\end{array}$ \\
\hline
\end{tabular}

${ }^{*}$ VTE—Venous thromboembolism; ${ }^{* *}$ LMWH—Low-molecular-weight heparins; ${ }^{* * *}$ DOAC—Direct Oral Anticoagulant; ${ }^{* * * *}$ ECMO— Extracorporeal membrane oxygenation.

In high-risk patients with no initial diagnosis of $\mathrm{PE}$, anticoagulant therapy may be empirically considered if they rapidly develop physico-clinical symptoms in accord with PE [102]. For confirmed PE in COVID-19 patients, administration of systemic anticoagulant therapy is highly recommended by the European Society of Cardiology [103]. However, this requires a thorough evaluation of contraindications, primarily those concerning bleeding. The precise dose of administration is evaluated as per the treatment regime of the institute and the treatment team. Parenteral therapy with LMWH and unfractionated heparin are the most commonly used anticoagulants in PE for COVID-19 patients [92]. LMWH is preferred in the current demanding situation owing to its cost-effectiveness and ease of availability [104]. The use of unfractionated heparin as an experimental therapy is strongly associated with improved survival in patients with markedly elevated D-dimer levels [105]. The therapy has the twofold advantage of having cytoprotective and antiviral effects besides having anticoagulant property [106]. Unfractionated heparin limits the fibrin deposition and microthrombus formation and is employed to treat systemic prothrombotic complications; however, clearance of fibrin clusters in the alveolar space cannot 
be achieved [107]. Perceptive monitoring of the patient is required to derive a therapeutically functional dose for unfractionated heparin therapy, while LMWH is used widely at a dose of $40 \mathrm{mg}$ or higher and requires no cautious monitoring [108]. Another beneficial aspect of LMWH therapy is a low tendency to induce bleeding and thrombocytopenia compared with UFH [106]. A delay or failure in the detection of heparin-induced thrombocytopenia is associated with poor outcomes of the treatment [109]. In patients with known heparin-induced thrombocytopenia, fondaparinux is the therapeutic agent of choice, besides argatroban being also administered widely $[109,110]$. It is being targeted by various expert groups to reach a dose beyond the standard dose to attain maximum benefit while overcoming the limitations of the standard dose. Even though standard pharmacological thromboprophylaxis is recommended in hospitalized patients, various expert groups have proposed to increase the dose of anticoagulants in critically ill patients with COVID-19. Tacquard et al. (2021) in their trial reported a higher prophylactic anticoagulation dose to be significantly associated with a reduced risk of thrombotic complications. Cumulative exposure to a higher prophylactic anticoagulant dose, however, was not associated with reduced mortality on day 14 and not associated with increased bleeding risk compared with standard dosing [111].

In a randomized controlled trial involving seriously ill COVID-19 patients, Bikdeli et al. (2020) aimed to infer whether an intermediate dose of anticoagulants apart from the standard dose could impart a benefit by decreasing the thrombotic event rates. An intermediate dose was thought to have the potential to confer a benefit while mitigating the high risk of bleeding associated with higher doses of therapeutic anticoagulation. The results from such trials can be of considerable importance in determining the efficacy of intermediate doses of anticoagulants [112].

Patients eligible for oral anticoagulants are preferred direct oral anticoagulant (DOAC) over a vitamin $\mathrm{K}$ antagonist, although warfarin or acenocoumarol are still used in numerous settings [113]. Recommendation of DOACs is possible only in patients with stable hemodynamics after an acute phase. High caution is recommended for a shift from vitamin $\mathrm{K}$ antagonists to DOACs in a presently pressing situation to avoid complications arising from erroneous change, leading to thromboembolism or bleeding [114]. A serious evaluation of drug-drug interactions of DOACs with antiviral therapies and the estimation of the risk of hepatic and renal toxicity are highly imperative in the prescription of DOACs. DOACs, when started after eliminating contraindications, bear a low-impact viral transmission for health-care personnel as regular and frequent blood tests are not required and abate heparin pseudo-resistance $[113,115]$. DOACs highly favor a timely discharge from the hospital but concurrently bear a risk of organ dysfunction, which may not be reversed in certain setups [116]. Although there are already existing practice guidelines for the recommended use of DOACs for patients with acute symptomatic VTE, different suggestions for the preferred anticoagulant in patients with COVID-19, particularly for the critically ill, have been made. The various recommendations made by the American College of Chest Physicians (CHEST) panel and other organizations after achieving a consensus on the use of DOACs in acutely and critically ill COVID-19 patients are as follows: (i) in acutely ill hospitalized patients with COVID-19, anticoagulant thromboprophylaxis with LMWH, fondaparinux, or UFH is recommended over anticoagulant thromboprophylaxis with a DOAC. The panel warns against the use of DOACs in these patients because of the high risk of rapid clinical deterioration in these patients. In addition, it is possible that most of these patients may be receiving antiviral agents or other investigational treatments that may significantly affect the pharmacodynamics of DOACs and hence increase the bleeding risk associated with the DOACs. (ii) In critically ill patients with COVID-19, the panel recommends anticoagulant thromboprophylaxis with LMWH or UFH over anticoagulant thromboprophylaxis with fondaparinux or a DOAC. The panel strongly warns against the use of DOACs in critically ill patients secondary to the high likelihood of drug-drug interactions, high possibility of acute kidney injury in these patients, and their hemodynamic instability. (iii) COVID-19 outpatients receiving warfarin who are unable to get 
international normalized ratio monitoring because of isolation may have DOACs initiated. The American College of Cardiology considers it reasonable to extend prophylaxis with LMWH or DOACs for up to 45 days in patients at a high risk of VTE and low risk of bleeding [92,115].

Thrombolytic therapy is conventionally reserved for COVID-19 patients with confirmed PE who are experiencing hemodynamic instability or hemodynamic collapse, with limited recommendation for hemodynamically stable patients [92,117]. Thrombolytic therapy has an overall limited efficacy in hemodynamically stable patients, and evidence does not strongly validate the treatment of COVID-19 pulmonary microthrombi in such patients. The therapy highly predisposes one to adverse events, while indications and contraindications for thrombolysis remain unchanged [117]. Systemic thrombolysis may be a preferred option for patients who are appropriate candidates for advanced therapy but unattainable for an invasive approach due to limited resources or viral transmission risks. Philippe et al. (2021) reported that systemic thrombolysis is highly effective in PE with right ventricular (RV) failure in patients with COVID-19 suffering from acute respiratory distress syndrome, with no cardiogenic shock. They reported seven patients; three had high-risk PE, and four had intermediate high-risk PE as per the European Society of Cardiology (ESC) severity scale. The systemic thrombolysis (recombinant tissue plasminogen activator) in the patients according to the standard protocol of $10 \mathrm{mg}$ for over $15 \mathrm{~min}$ and then $90 \mathrm{mg}$ for over $120 \mathrm{~min}$ was found to be associated with improved treatment outcomes [118]. Five patients had a reduction of the Brescia-COVID Respiratory Severity Scale besides a decrease of the RV dysfunction. They reported no major bleeding events after the thrombolysis; however, the mortality after systemic thrombolysis was up to three of seven patients. In a COVID-19 hospitalized patient presenting high-risk PE related to a right heart thrombus, Scudiero et al. (2020) found systemic thrombolysis to be highly effective and recommend the therapy for life-threatening PE in COVID-19 patients [119]. It is highly preferred to limit the use of catheter-directed therapies during the current outbreak unless warranted by critical situations to limit viral transmittance since inconsiderable data support lower mortality from routine use of advanced therapies [116,120]. Mechanical thromboprophylaxis becomes indispensable when pharmacological thromboprophylaxis is contraindicated especially in immobilized patients [116,121]. Pneumatic compression devices are most widely recommended as per the major societal recommendations and guidelines addressing the management of coagulopathy in COVID-19 patients and WHO [121,122]. A combined pharmacological and mechanical prophylaxis is not recommended unless the patient has a worsening trajectory and there is no contraindication for each modality [123]. Extracorporeal membrane oxygenation (ECMO) with catheter-directed treatment or surgical embolectomy is preferred in case of cardiac arrest or refractory shock to prevent worse outcomes. ECMO therapy needs to be given strictly following the existing anticoagulation guidelines to prevent thrombotic complications arising from the activation of the coagulation pathways due to the therapy itself, considering the hypercoagulable status of COVID-19 patients.

\section{Post-COVID-19 Thromboprophylaxis}

After discharge, VTE prophylaxis is not recommended for COVID-19 patients [124]. However, in patients treated for COVID-19 and predisposed moderately or severely to PE, a computed tomography pulmonary angiogram (CT-PE) within 1 month of being negative for COVID-19 may be recommended, if they had not undergone any diagnostic imaging due to the COVID-19 surge. In patients with a high risk of PE, a follow-up and 3 months of thromboprophylaxis may be recommended [110]. The Food and Drug Administration has approved rivaroxaban at $10 \mathrm{mg}$ daily for 31 to 39 days in such patients [125]. Telemedicine is an expedient method that can provide follow-up care to such vulnerable patients with minimal risk of viral transmission [126]. Hospitalized patients, when getting discharged and apparently seeming stable and asymptomatic, may still have the procoagulant effect of COVID-19 extended by a few weeks. This, combined with less mobility during hos- 
pitalization and other complications, puts the patient at a high suspicion of recurrent PE after discharge $[127,128]$. It is evident from retrospective observational cohort studies that COVID-19 patients discharged from the hospital without anticoagulation had a cumulative incidence of thrombosis $(2.5 \%)$, VTE $(0.6 \%)$, and major hemorrhage $(0.7 \%)$ with clinically relevant non-major bleeds (2.9\%) on day 30 following discharge [129]. The prevention of a repeated episode requires extending an outpatient VTE prophylaxis; however, the decision needs to balance the reduced risk of VTE with the risk of increased bleeding events. LMWH is preferred to DOAC due to potential drug-drug interactions and/or frequent comorbidities [102-121].

\section{Mortality}

Prior to the strike of the COVID-19 pandemic, time trend analyses suggested that case fatality rates of PE were decreasing in European, Asian, and North American populations over the last 15 years [98-117]. However, PE in COVID-19 patients is associated with clinical worsening of the disease outcome and increased mortality rate. Numerous studies strongly suggest PE in COVID-19 patients as an increased risk factor for mortality. Liao et al. (2020) reported a substantially high mortality rate (45\%) for COVID-19 patients with PE when compared with COVID-19 patients with no PE [23]. Bompard et al. (2020) also reported a higher mortality rate in a PE-positive group (13\%) than in a PE-negative group (12\%) [20]. With the cumulative incidence of death due to COVID-19 being about 1.8 million, the contribution of PE to mortality necessitates that first-line healthcare providers be cautious about the incidence of PE and its associated complications in COVID-19 patients [130] (Table 1).

\section{Conclusions}

COVID-19 has led to enormous human casualties, with PE being a major manifestation of the infection that increases the chance of worst outcomes of the disease and increases mortality. COVID-19-associated PE patients have increased the challenge to the health-care system and care providers. Overlapping symptoms with no well-known prior risk factors lead to undiagnosed PE in COVID-19 patients, especially in settings with limited resources. The differential characteristics of COVID-19-related PE and classical PE pose a challenge to treatment since patients have varied clinico-biological presentations. It requires a thorough evaluation of the risk stratification and course of disease to design a treatment regime, with careful assessment of contraindications for every patient. This calls for a multidisciplinary approach, which is constrained due to the overburden of patients and a high risk of viral transmittance. Although numerous guidelines have been issued to manage the condition, success has not been achieved to overcome its detrimental effects. This calls for more dedication in taking preventive measures to avoid viral exposure by the public in general and high-risk groups in particular.

Author Contributions: Conceptualization, M.S.A.; methodology, M.S.A.; formal analysis, M.S.A. and H.A.H.; writing—original draft preparation, M.S.A., H.R., and A.A.M.; writing—review and editing, A.B. and J.O.; visualization, A.B.; supervision, M.S.A., J.O., and A.B.; funding acquisition, M.S.A., H.A.H., H.R., A.A.M. and A.B. All authors have read and agreed to the published version of the manuscript.

Funding: This research received no external funding.

Institutional Review Board Statement: Since this is a review of scientific literature and does not involve the active participation of human or animals or their biological samples, ethical review and approval are not required for this study.

Informed Consent Statement: Not applicable.

Conflicts of Interest: The authors declare no conflict of interest. 


\section{References}

1. Worku, B.; Gulkarov, I.; Girardi, L.N.; Salemi, A. Pulmonary embolectomy in the treatment of submassive and massive pulmonary embolism. Cardiology 2014, 129, 106-110. [CrossRef] [PubMed]

2. Giordano, N.J.; Jansson, P.S.; Young, M.N.; Hagan, K.A.; Kabrhel, C. Epidemiology, Pathophysiology, Stratification, and Natural History of Pulmonary Embolism. Tech. Vasc. Interv. Radiol. 2017, 20, 135-140. [CrossRef] [PubMed]

3. Essien, E.O.; Rali, P.; Mathai, S.C. Pulmonary Embolism. Med. Clin. N. Am. 2019, 103, 549-564. [CrossRef] [PubMed]

4. Grimnes, G.; Isaksen, T.; Tichelaar, Y.I.G.V.; Braekkan, S.K.; Hansen, J.-B. Acute infection as a trigger for incident venous thromboembolism: Results from a population-based case-crossover study. Res. Pr. Thromb. Haemost. 2018, 2, 85-92. [CrossRef]

5. Matthews, J.C.; McLaughlin, V. Acute right ventricular failure in the setting of acute pulmonary embolism or chronic pulmonary hypertension: A detailed review of the pathophysiology, diagnosis, and management. Curr. Cardiol. Rev. 2008, 4, 49-59. [CrossRef]

6. Astuti, I.; Ysrafil. Severe Acute Respiratory Syndrome Coronavirus 2 (SARS-CoV-2): An overview of viral structure and host response. Diabetes Metab. Syndr. 2020, 14, 407-412. [CrossRef]

7. Kashani, K.B. Hypoxia in COVID-19: Sign of Severity or Cause for Poor Outcomes. Mayo Clin. Proc. 2020, 95, 1094-1096. [CrossRef]

8. Yang, X.; Yu, Y.; Xu, J.; Shu, H.; Xia, J.; Liu, H.; Wu, Y.; Zhang, L.; Yu, Z.; Fang, M.; et al. Clinical course and outcomes of critically ill patients with SARS-CoV-2 pneumonia in Wuhan, China: A single-centered, retrospective, observational study. Lancet Respir Med. 2020, 8, 475-481. [CrossRef]

9. Klok, F.A.; Kruip, M.J.H.A.; van der Meer, N.J.M.; Arbous, M.S.; Gommers, D.A.M.P.J.; Kant, K.M.; Kaptein, F.H.J.; van Paassen, J.; Stals, M.A.M.; Huisman, M.V.; et al. Incidence of thrombotic complications in critically ill ICU patients with COVID-19. Thromb. Res. 2020, 191, 145-147. [CrossRef]

10. Cui, S.; Chen, S.; Li, X.; Liu, S.; Wang, F. Prevalence of venous thromboembolism in patients with severe novel coronavirus pneumonia. J. Thromb. Haemost. 2020, 18, 1421-1424. [CrossRef]

11. Lorenzo, C.; Francesca, B.; Francesco, P.; Elena, C.; Luca, S.; Paolo, S. Acutepulmonary embolism in COVID-19 related hypercoagulability. J. Thromb. Thrombolysis 2020, 50, 223-226. [CrossRef] [PubMed]

12. Clark, A.C.; Xue, J.; Sharma, A. Pulmonary Embolism: Epidemiology, Patient Presentation, Diagnosis, and Treatment. J. Radiol. Nurs. 2019, 38, 112-118. [CrossRef]

13. Turetz, M.; Sideris, A.T.; Friedman, O.A.; Triphathi, N.; Horowitz, J.M. Epidemiology, Pathophysiology, and Natural History of Pulmonary Embolism. Semin. Interv. Radiol. 2018, 35, 92-98. [CrossRef] [PubMed]

14. Incidence of Pulmonary Embolism in ED Patients During the COVID-19 Pandemic. Available online: https://www.jwatch.org/ na52640/2020/10/14/incidence-pulmonary-embolism-ed-patients-during-covid-19 (accessed on 11 December 2020).

15. Roncon, L.; Zuin, M.; Barco, S.; Valerio, L.; Zuliani, G.; Zonzin, P.; Konstantinides, S.V. Incidence of acute pulmonary embolism in COVID-19 patients: Systematic review and meta-analysis. Eur. J. Intern. Med. 2020, 17, S0953-S6205.

16. COVID-19. Available online: https://www.hematology.org/covid (accessed on 12 October 2020).

17. Miesbach, W.; Makris, M. COVID-19: Coagulopathy, Risk of Thrombosis, and the Rationale for Anticoagulation. Clin. Appl. Thromb. 2020, 26, 107602962093814. [CrossRef]

18. Poissy, J.; Goutay, J.; Caplan, M.; Parmentier, E.; Duburcq, T.; Lassalle, F.; Jeanpierre, E.; Rauch, A.; Labreuche, J.; Susen, S.; et al. Pulmonary Embolism in Patients With COVID-19. Circ. 2020, 142, 184-186. [CrossRef] [PubMed]

19. Hauguel-Moreau, M.; El Hajjam, M.; De Baynast, Q.; Vieillard-Baron, A.; Lot, A.-S.; Chinet, T.; Mustafic, H.; Bégué, C.; Carlier, R.Y.; Geri, G.; et al. Occurrence of pulmonary embolism related to COVID-19. J. Thromb. Thrombolysis 2020, 6, 1-7. [CrossRef] [PubMed]

20. Bompard, F.; Monnier, H.; Saab, I.; Tordjman, M.; Abdoul, H.; Fournier, L.; Sanchez, O.; Lorut, C.; Chassagnon, G.; Revel, M.P. Pulmonary embolism in patients with COVID-19pneumonia. Eur. Respir J. 2020, 30, 2001365. [CrossRef] [PubMed]

21. Mestre-Gómez, B.; Lorente-Ramos, R.M.; Rogado, J.; Franco-Moreno, A.; Obispo, B.; Salazar-Chiriboga, D.; Saez-Vaquero, T.; Torres-Macho, J.; Abad-Motos, A.; Cortina-Camarero, C.; et al. Infanta Leonor Thrombosis Research Group. Incidence of pulmonary embolism in non-critically ill COVID-19 patients. Predicting factors for a challenging diagnosis. J. Thromb. Thrombolysis 2020, 29, 1-7.

22. Benito, N.; Filella, D.; Mateo, J.; Fortuna, A.M.; Gutierrez-Alliende, J.E.; Hernandez, N.; Gimenez, A.M.; Pomar, V.; Castellvi, I.; Corominas, H.; et al. Pulmonary Thrombosis or Embolism in a Large Cohort of Hospitalized Patients with Covid-19. Front. Med. 2020, 7, 557. [CrossRef]

23. Liao, S.-C.; Shao, S.-C.; Chen, Y.-T.; Chen, Y.-C.; Hung, M.-J. Incidence and mortality of pulmonary embolism in COVID-19: A systematic review and meta-analysis. Crit. Care 2020, 24, 464. [CrossRef]

24. Piroth, L.; Cottenet, J.; Mariet, A.-S.; Bonniaud, P.; Blot, M.; Tubert-Bitter, P.; Quantin, C. Comparison of the characteristics, morbidity, and mortality of COVID-19 and seasonal influenza: A nationwide, population-based retrospective cohort study. Lancet Respir. Med. 2020, 17, 251-259.

25. Jiménez, D.; García-Sanchez, A.; Rali, P.; Muriel, A.; Bikdeli, B.; Ruiz-Artacho, P.; Le Mao, R.; Rodríguez, C.; Hunt, B.J.; Monreal, M. Incidence of VTE and Bleeding Among Hospitalized Patients with Coronavirus Disease 2019. Chest 2020, 17, 1182-1196.

26. Zhang, R.; Ni, L.; Di, X.; Wang, X.; Ma, B.; Niu, S.; Liu, C. Systematic review and meta-analysis of the prevalence of venous thromboembolic events in novel coronavirus disease-2019 patients. J. Vasc. Surgery Venous Lymphat. Disord. 2021, 9, $289-298$. 
27. Suh, Y.J.; Hong, H.; Ohana, M.; Bompard, F.; Revel, M.-P.; Valle, C.; Gervaise, A.; Poissy, J.; Susen, S.; Hékimian, G.; et al. Pulmonary Embolism and Deep Vein Thrombosis in COVID-19: A Systematic Review and Meta-Analysis. Radiology 2021, 15, 203557.

28. Abate, S.M.; Ali, S.A.; Mantfardo, B.; Basu, B. Rate of Intensive Care Unit admission and outcomes among patients with coronavirus: A systematic review and Meta-analysis. PLoS ONE 2020, 15, e0235653. [CrossRef]

29. Boonyawat, K.; Chantrathammachart, P.; Numthavaj, P.; Nanthatanti, N.; Phusanti, S.; Phuphuakrat, A.; Niparuck, P.; Angchaisuksiri, P. Incidence of thromboembolism in patients with COVID-19: A systematic review and meta-analysis. Thromb. J. 2020, 23, 34. [CrossRef]

30. Artifoni, M.; Danic, G.; Gautier, G.; Gicquel, P.; Boutoille, D.; Raffi, F.; Neel, A.; Lecomte, R. Systematic assessment of venous thromboembolism in COVID-19 patients receiving thromboprophylaxis: Incidence and role of D-dimer as predictive factors. J. Thromb. Thrombolysis 2020, 50, 211-216. [CrossRef] [PubMed]

31. Lodigiani, C.; Iapichino, G.; Carenzo, L.; Cecconi, M.; Ferrazzi, P.; Sebastian, T.; Kucher, N.; Studt, J.D.; Sacco, C.; Bertuzzi, A.; et al. Humanitas COVID-19 Task Force. Venous and arterial thromboembolic complications in COVID-19 patients admitted to an academic hospital in Milan, Italy. Thromb. Res 2020, 191, 9-14. [CrossRef] [PubMed]

32. Grillet, F.; Behr, J.; Calame, P.; Aubry, S.; Delabrousse, E. Acute Pulmonary Embolism Associated with COVID-19 Pneumonia Detected with Pulmonary CT Angiography. Radiology 2020, 296, E186-E188. [CrossRef]

33. Leonard-Lorant, I.; Delabranche, X.; Séverac, F.; Helms, J.; Pauzet, C.; Collange, O.; Schneider, F.; Labani, A.; Bilbault, P.; Molière, S.; et al. Acute Pulmonary Embolism in Patients with COVID-19 at CT Angiography and Relationship to d-Dimer Levels. Radiology 2020, 296, E189-E191. [CrossRef]

34. Llitjos, J.; Leclerc, M.; Chochois, C.; Monsallier, J.; Ramakers, M.; Auvray, M.; Merouani, K. High incidence of venous thromboembolic events in anticoagulated severe COVID-19 patients. J. Thromb. Haemost. 2020, 18, 1743-1746. [CrossRef] [PubMed]

35. Thomas, W.; Varley, J.; Johnston, A.; Symington, E.; Robinson, M.; Sheares, K.; Lavinio, A.; Besser, M. Thrombotic complications of patients admitted to intensive care with COVID-19 at a teaching hospital in the United Kingdom. Thromb. Res. 2020, 191, 76-77. [CrossRef] [PubMed]

36. Middeldorp, S.; Coppens, M.; Van Haaps, T.F.; Foppen, M.; Vlaar, A.P.; Müller, M.C.A.; Bouman, C.C.S.; Beenen, L.F.M.; Kootte, R.S.; Heijmans, J.; et al. Incidence of venous thromboembolism in hospitalized patients with COVID-19. J. Thromb. Haemost. 2020, 18, 1995-2002. [CrossRef] [PubMed]

37. Helms, J.; Tacquard, C.; Severa, F.; Leonard-Lorant, I.; Ohana, M.; Delabranche, X.; Merdji, H.; Clere-Jehl, R.; Schenck, M.; Fagot Gandet, F; et al. CRICS TRIGGERSEP Group (Clinical Research in Intensive Care and Sepsis Trial Group for Global Evaluation and Research in Sepsis). High risk of thrombosis in patients with severe SARS-CoV-2 infection: A multicenter prospective cohort study. Intensive Care Med. 2020, 46, 1089-1098. [CrossRef]

38. Hékimian, G.; Lebreton, G.; Bréchot, N.; Luyt, C.-E.; Schmidt, M.; Combes, A. Severe pulmonary embolism in COVID-19 patients: A call for increased awareness. Crit. Care 2020, 24, 274. [CrossRef]

39. Galeano-Valle, F.; Oblitas, C.M.; Ferreiro-Mazón, M.M.; Alonso-Muñoz, J.; Del Toro-Cervera, J.; di Natale, M.; Demelo-Rodríguez, P. Antiphospholipid antibodies are not elevated in patients with severe COVID-19 pneumonia and venous thromboembolism. Thromb. Res. 2020, 192, 113-115. [CrossRef]

40. Soumagne, T.; Lascarrou, J.-B.; Hraiech, S.; Horlait, G.; Higny, J.; D’Hondt, A.; Grimaldi, D.; Gaudry, S.; Courcelle, R.; Carbutti, G.; et al. Factors Associated with Pulmonary Embolism Among Coronavirus Disease 2019 Acute Respiratory Distress Syndrome: A Multicenter Study Among 375 Patients. Crit. Care Explor. 2020, 2, e0166. [CrossRef]

41. Fraissé, M.; Logre, E.; Pajot, O.; Mentec, H.; Plantefève, G.; Contou, D. Thrombotic and hemorrhagic events in critically ill COVID-19 patients: A French monocenter retrospective study. Crit. Care 2020, 2, 275. [CrossRef]

42. Freund, Y.; Drogrey, M.; Miró, O.; Marra, A.; Féral-Pierssens, A.L.; Penaloza, A.; Hernandez, B.A.L.; Beaune, S.; Gorlicki, J.; Vaittinada, A.P.; et al. Improving emergency care fhu Collaborators. Association Between Pulmonary Embolism and COVID-19 in Emergency Department Patients Undergoing Computed Tomography Pulmonary Angiogram: The PEPCOV International Retrospective Study. Acad. Emerg. Med. 2020, 30, 811-820. [CrossRef]

43. Chen, J.; Wang, X.; Zhang, S.; Lin, B.; Wu, X.; Wang, Y.; Wang, X.; Yang, M.; Sun, J.; Xie, Y. Characteristics of Acute Pulmonary Embolism in Patients With COVID-19 Associated Pneumonia from the City of Wuhan. Clin. Appl. Thromb. Hemost. 2020, 26, 1076029620936772. [CrossRef]

44. Longchamp, A.; Longchamp, J.; Manzocchi-Besson, S.; Whiting, L.; Haller, C.; Jeanneret, S.; Godio, M.; Garcia Martinez, J.J.; Bonjour, T.; Caillat, M.; et al. Venous thromboembolism in critically Ill patients with COVID-19: Results of a screening study for deep vein thrombosis. Res. Pract. Thromb. Haemost. 2020, 30, 842-847. [CrossRef]

45. Whyte, M.B.; Kelly, P.A.; Gonzalez, E.; Arya, R.; Roberts, L.N. Pulmonary embolism in hospitalised patients with COVID-19. Thromb. Res. 2020, 195, 95-99. [CrossRef]

46. Marone, E.M.; Bonalumi, G.; Curci, R.; Arzini, A.; Chierico, S.; Marazzi, G.; Diaco, D.A.; Rossini, R.; Boschini, S.; Rinaldi, L.F. Characteristics of Venous Thromboembolism in COVID-19 Patients: A Multicenter Experience from Northern Italy. Ann. Vasc. Surg. 2020, 68, 83-87. [CrossRef]

47. Fauvel, C.; Weizman, O.; Trimaille, A.; Mika, D.; Pommier, T.; Pace, N.; Douair, A.; Barbin, E.; Fraix, A.; Bouchot, O.; et al. Critical Covid-19 France Investigators. Pulmonary embolism in COVID-19patients: A French multicentre cohort study. Eur. Heart J. 2020, 41, 3058-3068. [CrossRef] [PubMed] 
48. Van den Heuvel, F.M.A.; Vos, J.L.; Koop, Y.; Van Dijk, A.P.J.; Duijnhouwer, A.L.; De Mast, Q.; Van De Veerdonk, F.L.; Bosch, F.; Kok, B.; Netea, M.G.; et al. Cardiac function in relation to myocardial injury in hospitalised patients with COVID-19. Neth. Hear. J. 2020, 28, 410-417. [CrossRef]

49. Faggiano, P.; Bonelli, A.; Paris, S.; Milesi, G.; Bisegna, S.; Bernardi, N.; Curnis, A.; Agricola, E.; Maroldi, R. Acute pulmonary embolism in COVID-19 disease: Preliminary report on seven patients. Int. J. Cardiol. 2020, 313, 129-131. [CrossRef] [PubMed]

50. Gervaise, A.; Bouzad, C.; Peroux, E.; Helissey, C. Acute pulmonary embolism in non-hospitalized COVID-19 patients referred to CTPA by emergency department. Eur. Radiol. 2020, 30, 6170-6177. [CrossRef] [PubMed]

51. Trimaille, A.; Curtiaud, A.; Marchandot, B.; Matsushita, K.; Sato, C.; Leonard-Lorant, I.; Sattler, L.; Grunebaum, L.; Ohana, M.; Von Hunolstein, J.-J.; et al. Venous thromboembolism in non-critically ill patients with COVID-19 infection. Thromb. Res. 2020, 193, 166-169. [CrossRef]

52. News, Coronavirus: Covid-19 has Killed More People than SARS and MERS Combined, Despite Lower Case Fatality Rate. Available online: https:/ / www.bmj.com/content/368/bmj.m641 (accessed on 15 January 2020).

53. Martin, A.I.; Rao, G. COVID-19: A Potential Risk Factor for Acute Pulmonary Embolism. Methodist. Debakey Cardiovasc. J 2020, 16, 155-157.

54. García-Ortega, A.; Oscullo, G.; Calvillo, P.; López-Reyes, R.; Méndez, R.; Gómez-Olivas, J.D.; Bekki, A.; Fonfría, C.; Trilles-Olaso, L.; Zaldívar, E.; et al. Incidence, risk factors, and thrombotic load of pulmonary embolism in patients hospitalized for COVID-19 infection. J. Infect. 2021, 82, 261-269. [CrossRef]

55. Danzi, G.B.; Loffi, M.; Galeazzi, G.; Gherbesi, E. Acute pulmonary embolism and COVID-19 pneumonia: A random association? Eur. Hear. J. 2020, 41, 1858. [CrossRef] [PubMed]

56. Poyiadji, N.; Cormier, P.; Patel, P.Y.; Hadied, M.O.; Bhargava, P.; Khanna, K.; Nadig, J.; Keimig, T.; Spizarny, D.; Reeser, N.; et al. Acute Pulmonary Embolism and COVID-19. Radiology 2020, 297, 201955. [CrossRef]

57. Sanfilippo, F.; La Rosa, V.; Oliveri, F.; Astuto, M. Convalescent plasma for COVID-19: The risk of pulmonary embolism should not be underestimated! Crit. Care 2020, 28, 531. [CrossRef]

58. Kowalewski, M.; Fina, D.; Słomka, A.; Raffa, G.M.; Martucci, G.; Coco, V.L.; De Piero, M.E.; Ranucci, M.; Suwalski, P.; Lorusso, R. COVID-19 and ECMO: The interplay between coagulation and inflammation-A narrative review. Crit. Care 2020, 24, 205. [CrossRef] [PubMed]

59. Von Bahr, V.; E Millar, J.; Malfertheiner, M.V.; Ki, K.K.; Passmore, M.R.; Bartnikowski, N.; A Redd, M.; Cavaye, M.; Suen, J.Y.; McAuley, D.F.; et al. Mesenchymal stem cells may ameliorate inflammation in an ex vivo model of extracorporeal membrane oxygenation. Perfusion 2019, 34, 15-21. [CrossRef] [PubMed]

60. Riedel, M. Acute pulmonary embolism 1: Pathophysiology, clinical presentation, and diagnosis. Heart 2001, 85, 229-240. [CrossRef]

61. Ciceri, F.; Castagna, A.; Rovere-Querini, P.; De Cobelli, F.; Ruggeri, A.; Galli, L.; Conte, C.; De Lorenzo, R.; Poli, A.; Ambrosio, A.; et al. Early predictors of clinical outcomes of COVID-19 outbreak in Milan, Italy. Clin. Immunol. 2020, $217,108509$. [CrossRef] [PubMed]

62. Manne, B.K.; Denorme, F.; Middleton, E.A.; Portier, I.; Rowley, J.W.; Stubben, C.J.; Petrey, A.C.; Tolley, N.D.; Guo, L.; Cody, M.J.; et al. Platelet gene expression and function in patients with COVID-19. Blood 2020, 136, 1317-1329. [CrossRef]

63. Teuwen, L.-A.; Geldhof, V.; Pasut, A.; Carmeliet, P. COVID-19: The vasculature unleashed. Nat. Rev. Immunol. 2020, 20, 389-391. [CrossRef] [PubMed]

64. Goshua, G.; Pine, A.B.; Meizlish, M.L.; Chang, C.-H.; Zhang, H.; Bahel, P.; Baluha, A.; Bar, N.; Bona, R.D.; Burns, A.J.; et al. Endotheliopathy in COVID-19-associated coagulopathy: Evidence from a single-centre, cross-sectional study. Lancet Haematol. 2020, 7, e575-e582. [CrossRef]

65. Hottz, E.D.; Azevedo-Quintanilha, I.G.; Palhinha, L.; Teixeira, L.; Barreto, E.A.; Pão, C.R.R.; Righy, C.; Franco, S.; Souza, T.M.L.; Kurtz, P.; et al. Platelet activation and platelet-monocyte aggregate formation trigger tissue factor expression in patients with severe COVID-19. Blood 2020, 136, 1330-1341. [CrossRef]

66. Wang, J.; Li, Q.; Yin, Y.; Zhang, Y.; Cao, Y.; Lin, X.; Huang, L.; Hoffmann, D.; Lu, M.; Qiu, Y. Excessive Neutrophils and Neutrophil Extracellular Traps in COVID-19. Front. Immunol. 2020, 18, 2063. [CrossRef] [PubMed]

67. Middleton, E.A.; He, X.Y.; Denorme, F.; Campbell, R.A.; Ng, D.; Salvatore, S.P.; Mostyka, M.; Baxter-Stoltzfus, A.; Borczuk, A.C.; Loda, M.; et al. Neutrophil extracellular traps contribute to immunothrombosis in COVID-19 acute respiratory distress syndrome. Blood 2020, 3, 1169-1179. [CrossRef] [PubMed]

68. Amraei, R.; Rahimi, N. COVID19, Renin-Angiotensin System and Endothelial Dysfunction. Cells 2020, 9, 1652. [CrossRef] [PubMed]

69. Hoffmann, M.; Kleine-Weber, H.; Schroeder, S.; Krüger, N.; Herrler, T.; Erichsen, S.; Schiergens, T.S.; Herrler, G.; Wu, N.H.; Nitsche, A.; et al. SARS-CoV-2 Cell Entry Depends on ACE2 and TMPRSS2 and Is Blocked by a Clinically Proven Protease Inhibitor. Cell 2020, 16, 271-280.e8. [CrossRef]

70. Verdecchia, P.; Cavallini, C.; Spanevello, A.; Angeli, F. The pivotal link between ACE2 deficiency and SARS-CoV-2 infection. Eur. J. Intern. Med. 2020, 76, 14-20. [CrossRef] [PubMed]

71. Garvin, M.R.; Alvarez, C.; Miller, J.I.; Prates, E.T.; Walker, A.M.; Amos, B.K.; Mast, A.E.; Justice, A.; Aronow, B.; Jacobson, D.A. A mechanistic model and therapeutic interventions for COVID-19 involving a RAS-mediated bradykinin storm. eLife 2020, 9 , e59177. [CrossRef] [PubMed] 
72. Schmaier, A.H. The contact activation and kallikrein/kinin systems: Pathophysiologic and physiologic activities. J. Thromb. Haemost. 2016, 14, 28-39. [CrossRef]

73. Stavrou, E.X.; Fang, C.; Merkulova, A.; Alhalabi, O.; Grobe, N.; Antoniak, S.; Mackman, N.; Schmaier, A.H. Reduced thrombosis in Klkb1-/- mice is mediated by increased Mas receptor, prostacyclin, Sirt1, and KLF4 and decreased tissue factor. Blood 2015, 22, 710-719. [CrossRef]

74. Sinha, P.; Matthay, M.A.; Calfee, C.S. Is a "Cytokine Storm" Relevant to COVID-19? JAMA Intern. Med. 2020, 1, 1152-1154. [CrossRef]

75. Leisman, D.E.; Deutschman, C.S.; Legrand, M. Facing, COVID-19 in the ICU: Vascular dysfunction, thrombosis, and dysregulated inflammation. Intensive Care Med. 2020, 46, 1105-1108. [CrossRef]

76. Channappanavar, R.; Perlman, S. Pathogenic human coronavirus infections: Causes and consequences of cytokine storm and immunopathology. Semin. Immunopathol. 2017, 39, 529-539. [CrossRef]

77. Tay, M.Z.; Poh, C.M.; Rénia, L.; Macary, P.A.; Ng, L.F.P. The trinity of COVID-19: Immunity, inflammation and intervention. Nat. Rev. Immunol. 2020, 20, 363-374. [CrossRef] [PubMed]

78. Mehta, P.; McAuley, D.F.; Brown, M.; Sanchez, E.; Tattersall, R.S.; Manson, J.J. COVID-19: Consider cytokine storm syndromes and immunosuppression. Lancet 2020, 395, 1033-1034. [CrossRef]

79. Chen, G.; Wu, D.; Guo, W.; Cao, Y.; Huang, D.; Wang, H.; Wang, T.; Zhang, X.; Chen, H.; Yu, H.; et al. Clinical and immunological features of severe and moderate coronavirus disease 2019. J. Clin. Investig. 2020, 130, 2620-2629. [CrossRef]

80. Zhou, F.; Yu, T.; Du, R.; Fan, G.; Liu, Y.; Liu, Z.; Xiang, J.; Wang, Y.; Song, B.; Gu, X.; et al. Clinical course and risk factors for mortality of adult inpatients with COVID-19 in Wuhan, China: A retrospective cohort study. Lancet 2020, 395, 1054-1062. [CrossRef]

81. Magro, C.; Mulvey, J.J.; Berlin, D.; Nuovo, G.; Salvatore, S.; Harp, J.; Baxter-Stoltzfus, A.; Laurence, J. Complement associated microvascular injury and thrombosis in the pathogenesis of severe COVID-19 infection: A report of five cases. Transl. Res. 2020, 220, 1-13. [CrossRef] [PubMed]

82. Zucoloto, A.Z.; Jenne, C.N. Platelet-Neutrophil Interplay: Insights into Neutrophil Extracellular Trap (NET)-Driven Coagulation in Infection. Front Cardiovasc. Med. 2019, 20, 85. [CrossRef] [PubMed]

83. Mancini, I.; Baronciani, L.; Artoni, A.; Colpani, P.; Biganzoli, M.; Cozzi, G.; Novembrino, C.; Anzoletti, M.B.; De Zan, V.; Pagliari, M.T.; et al. The ADAMTS13-von Willebrand factor axis in COVID-19 patients. J. Thromb. Haemost. 2021, 19. [CrossRef]

84. Kyrle, P.A.; Minar, E.; Hirschl, M.; Bialonczyk, C.; Stain, M.; Schneider, B.; Weltermann, A.; Speiser, W.; Lechner, K.; Eichinger, S. High Plasma Levels of Factor VIII and the Risk of Recurrent Venous Thromboembolism. N. Engl. J. Med. 2000, 343, 457-462. [CrossRef] [PubMed]

85. Li, J.; Wang, X.; Chen, J.; Cai, Y.; Deng, A.; Yang, M. Association between ABO blood groups and risk of SARS-CoV-2 pneumonia. Br. J. Haematol. 2020, 190, 24-27. [CrossRef] [PubMed]

86. O'Donnell, J.; Laffan, M.A. The relationship between ABO histo-blood group, factor VIII and von Willebrand factor. Transfus. Med. 2001, 11, 343-351. [CrossRef] [PubMed]

87. Palevsky, H.I. The problems of the clinical and laboratory diagnosis of pulmonary embolism. Semin. Nucl. Med. 1991, 21, 276-280. [CrossRef]

88. Howard, L. Acute pulmonary embolism. Clin. Med. 2019, 19, 243-247. [CrossRef]

89. Lavorini, F.; Di Bello, V.; De Rimini, M.L.; Lucignani, G.; Marconi, L.; Palareti, G.; Pesavento, R.; Prisco, D.; Santini, M.; Sverzellati, N.; et al. Diagnosis and treatment of pulmonary embolism: A multidisciplinary approach. Multidiscip. Respir Med. 2013, 19, 75. [CrossRef] [PubMed]

90. Righini, M.; Robert-Ebadi, H. Diagnosis of acute Pulmonary Embolism. Hamostaseologie 2018, 38, 11-21. [CrossRef]

91. Adams, E.; Broce, M.; Mousa, A. Proposed Algorithm for Treatment of Pulmonary Embolism in COVID-19 Patients. Ann. Vasc. Surg. 2021, 70, 282-285. [CrossRef] [PubMed]

92. Rosovsky, R.P.; Grodzin, C.; Channick, R.; Davis, G.A.; Giri, J.S.; Horowitz, J.; Kabrhel, C.; Lookstein, R.; Merli, G.; Morris, T.A.; et al. Diagnosis and Treatment of Pulmonary Embolism During the Coronavirus Disease 2019 Pandemic. Chest 2020, 158, 2590-2601. [CrossRef]

93. Iba, T.; Connors, J.M.; Levy, J.H. The coagulopathy, endotheliopathy, and vasculitis of COVID-19. Inflamm. Res. 2020, 69, 1181-1189. [CrossRef]

94. Parks, A.L.; Auerbach, A.D.; Schnipper, J.L.; Anstey, J.E.; Sterken, D.G.; Hecht, T.E.; Fang, M.C.; Vaughn, V.M.; Dunn, A.S.; Linker, A.S.; et al. COVID-19 coagulopathy and thrombosis: Analysis of hospital protocols in response to the rapidly evolving pandemic. Thromb. Res. 2020, 196, 355-358. [CrossRef] [PubMed]

95. Vidali, S.; Morosetti, D.; Cossu, E.; Luisi, M.L.E.; Pancani, S.; Semeraro, V.; Consales, G. D-dimer as an indicator of prognosis in SARS-CoV-2 infection: A systematic review. ERJ Open Res. 2020, 13, 260-2020. [CrossRef] [PubMed]

96. Parry, A.H.; Wani, A.H. Pulmonary embolism in coronavirus disease-19 (COVID-19) and use of compression ultrasonography in its optimal management. Thromb. Res. 2020, 192, 36. [CrossRef]

97. Zhang, L.; Wang, B.; Zhou, J.; Kirkpatrick, J.; Xie, M.; Johri, A.M. Bedside Focused Cardiac Ultrasound in COVID-19 from the Wuhan Epicenter: The Role of Cardiac Point-of-Care Ultrasound, Limited Transthoracic Echocardiography, and Critical Care Echocardiography. J. Am. Soc. Echocardiogr. 2020, 33, 676-682. [CrossRef] 
98. Dweck, M.R.; Bularga, A.; Hahn, R.T.; Bing, R.; Lee, K.K.; Chapman, A.R.; White, A.; Di Salvo, G.; Sade, L.E.; Pearce, K.; et al. Global evaluation of echocardiography in patients with COVID-19. Eur. Hear. J. Cardiovasc. Imaging 2020, 21, 949-958. [CrossRef] [PubMed]

99. Scudiero, F.; Silverio, A.; Di Maio, M.; Russo, V.; Citro, R.; Personeni, D.; Cafro, A.; D'Andrea, A.; Attena, E.; Pezzullo, S.; et al. Cov-IT Network. Pulmonary embolism in COVID-19 patients: Prevalence, predictors and clinical outcome. Thromb. Res. 2020, 17, 34-39.

100. Kostadima, E.; Zakynthinos, E. Pulmonary embolism: Pathophysiology, diagnosis, treatment. Hell. J. Cardiol. $2007,48,94-107$.

101. A Systematic Approach for Managing Venous Thromboembolism in Patients with Covid-19. Available online: https://www.isth. org/news/517212 (accessed on 20 January 2020).

102. Coppola, A.; Tagliaferri, A.; Rivolta, G.F.; Quintavalle, G.; Franchini, M. Confronting COVID-19: Issues in Hemophilia and Congenital Bleeding Disorders. Semin. Thromb. Hemost. 2020, 46, 819-822. [PubMed]

103. ESC Guidance for the Diagnosis and Management of CV Disease during the COVID-19 Pandemic. Available online: https: / / www.escardio.org/Education/COVID-19-and-Cardiology/ESC-COVID-19-Guidance (accessed on 17 January 2021).

104. Hosseini, A.; Bahramnezhad, F. Pulmonary embolism in patients with COVID-19 and its treatment based on low-molecular-weight heparin. Sao Paulo Med J. 2020, 138, 349-351. [CrossRef]

105. Tang, N.; Bai, H.; Chen, X.; Gong, J.; Li, D.; Sun, Z. Anticoagulant treatment is associated with decreased mortality in severe coronavirus disease 2019 patients with coagulopathy. J. Thromb. Haemost. 2020, 18, 1094-1099. [CrossRef]

106. Kipshidze, N.; Dangas, G.; White, C.J.; Kipshidze, N.; Siddiqui, F.; Lattimer, C.R.; Carter, C.A.; Fareed, J. Viral Coagulopathy in Patients With COVID-19: Treatment and Care. Clin. Appl. Thromb. 2020, 26, 1076029620936776. [CrossRef] [PubMed]

107. Tersalvi, G.; Vicenzi, M.; Calabretta, D.; Biasco, L.; Pedrazzini, G.; Winterton, D. Elevated Troponin in Patients with Coronavirus Disease 2019: Possible Mechanisms. J. Card. Fail 2020, 26, 470-475. [CrossRef]

108. Cohoon, K.P.; Mahé, G.; Tafur, A.J.; Spyropoulos, A.C. Emergence of institutional antithrombotic protocols for coronavirus 2019. Res. Pr. Thromb. Haemost. 2020, 4, 510-517. [CrossRef] [PubMed]

109. Riker, R.R.; May, T.L.; Fraser, G.L.; Gagnon, D.J.; Bandara, M.; Zemrak, W.R.; Seder, D.B. Heparin-induced thrombocytopenia with thrombosis in COVID-19 adult respiratory distress syndrome. Res. Pr. Thromb. Haemost. 2020, 4, 936-941. [CrossRef]

110. Obi, A.T.; Barnes, G.D.; Wakefield, T.W.; Brown, S.; Eliason, J.L.; Arndt, E.; Henke, P.K. Practical diagnosis and treatment of suspected venous thromboembolism during COVID-19 pandemic. J. Vasc. Surgery: Venous Lymphat. Disord. 2020, 8, 526-534. [CrossRef]

111. Tacquard, C.; Mansour, A.; Godon, A.; Godet, J.; Poissy, J.; Garrigue, D.; Kipnis, E.; Hamada, S.R.; Mertes, P.M.; Steib, A.; et al Impact of high dose prophylactic anticoagulation in critically ill patients with COVID-19 pneumonia. Chest 2021, 16. (In Press)

112. Bikdeli, B.; Talasaz, A.H.; Rashidi, F.; Sharif-Kashani, B.; Farrokhpour, M.; Bakhshandeh, H.; Sezavar, H.; Dabbagh, A.; Beigmohammadi, M.T.; Payandemehr, P.; et al. Intermediate versus standard-dose prophylactic anticoagulation and statin therapy versus placebo in critically-ill patients with COVID-19: Rationale and design of the INSPIRATION/INSPIRATION-S studies. Thromb. Res. 2020, 196, 382-394. [CrossRef]

113. Kosior, D.A.; Undas, A.; Kopeć, G.; Hryniewiecki, T.; Torbicki, A.; Mularek-Kubzdela, T.; Windyga, J.; Pruszczyk, P. Guidance for anticoagulation management in venous thromboembolism during the coronavirus disease 2019 (COVID-19) pandemic in Poland: An expert opinion of the Section on Pulmonary Circulation of the Polish Cardiac Society. Kardiologia Polska 2020, 25, 642-646. [CrossRef]

114. Sakr, Y.; Giovini, M.; Leone, M.; Pizzilli, G.; Kortgen, A.; Bauer, M.; Tonetti, T.; Duclos, G.; Zieleskiewicz, L.; Buschbeck, S.; et al. Pulmonary embolism in patients with coronavirus disease-2019 (COVID-19) pneumonia, a narrative review. Ann. Intensive Care 2020, 16, 124. [CrossRef]

115. Moores, L.K.; Tritschler, T.; Brosnahan, S.; Carrier, M.; Collen, J.F.; Doerschug, K.; Holley, A.B.; Jimenez, D.; Le Gal, G.; Rali, P.; et al. Prevention, Diagnosis, and Treatment of VTE in Patients with Coronavirus Disease 2019. Chest 2020, 158, 1143-1163. [CrossRef] [PubMed]

116. Bikdeli, B.; Madhavan, M.V.; Jimenez, D.; Chuich, T.; Dreyfus, I.; Driggin, E.; Nigoghossian, C.; Ageno, W.; Madjid, M.; Guo, Y.; et al. Global COVID-19 Thrombosis Collaborative Group, Endorsed by the ISTH, NATF, ESVM, and the IUA, Supported by the ESC Working Group on Pulmonary Circulation and Right Ventricular Function. COVID-19 and Thrombotic or Thromboembolic Disease: Implications for Prevention, Antithrombotic Therapy, and Follow-Up: JACC State-of-the-Art Review. J. Am. Coll. Cardiol 2020, 16, 2950-2973.

117. Konstantinides, S.V.; Meyer, G.; Becattini, C.; Bueno, H.; Geersing, G.J.; Harjola, V.P.; Huisman, M.V.; Humbert, M.; Jennings, C.S.; Jiménez, D. The Task Force for the diagnosis and management of acute pulmonary embolism of the European Society of Cardiology (ESC). 2019 ESC Guidelines for the diagnosis and management of acute pulmonary embolism developed in collaboration with the European Respiratory Society (ERS); The Task Force for the diagnosis and management of acute pulmonary embolism of the European Society of Cardiology (ESC). Eur. Respir J. 2019, 9, 1901647.

118. Philippe, J.; Cordeanu, E.-M.; Leimbach, M.-B.; Greciano, S.; Younes, W. Acute pulmonary embolism and systemic thrombolysis in the era of COVID-19 global pandemic 2020: A case series of seven patients admitted to a regional hospital in the French epidemic cluster. Eur. Hear. J. Case Rep. 2021, 5, 522. [CrossRef] [PubMed]

119. Scudiero, F.; Pitì, A.; Keim, R.; Parodi, G. Acute pulmonary embolism in COVID-19 patient: A case report of free-floating right heart thrombus successfully treated with fibrinolysis. Eur. Hear. J. Case Rep. 2021, 5, ytaa388. [CrossRef] 
120. Giri, J.; Sista, A.K.; Weinberg, I.; Kearon, C.; Kumbhani, D.J.; Desai, N.D.; Piazza, G.; Gladwin, M.T.; Chatterjee, S.; Kobayashi, T.; et al. Interventional Therapies for Acute Pulmonary Embolism: Current Status and Principles for the Development of Novel Evidence: A Scientific Statement from the American Heart Association. Circ. 2019, 140, e774-e801. [CrossRef]

121. Flaczyk, A.; Rosovsky, R.P.; Reed, C.T.; Bankhead-Kendall, B.K.; Bittner, E.A.; Chang, M.G. Comparison of published guidelines for management of coagulopathy and thrombosis in critically ill patients with COVID 19: Implications for clinical practice and future investigations. Crit. Care 2020, 16, 559. [CrossRef]

122. Greenall, R.; E Davis, R. Intermittent pneumatic compression for venous thromboembolism prevention: A systematic review on factors affecting adherence. BMJ Open 2020, 10, e037036. [CrossRef]

123. Witt, D.M.; Nieuwlaat, R.; Clark, N.P.; Ansell, J.; Holbrook, A.; Skov, J.; Shehab, N.; Mock, J.; Myers, T.; Dentali, F.; et al. American Society of Hematology 2018 guidelines for management of venous thromboembolism: Optimal management of anticoagulation therapy. Blood Adv. 2018, 2, 3257-3291. [CrossRef]

124. COVID-19 Treatment Guidelines Panel. Coronavirus Disease 2019 (COVID-19) Treatment Guidelines. National Institutes of Health. Available online: https: / www.covid19treatmentguidelines.nih.gov / (accessed on 17 January 2021).

125. Antithrombotic Therapy in Patients with COVID-19. Available online: https://www.covid19treatmentguidelines.nih.gov/ adjunctive-therapy/antithrombotic-therapy/ (accessed on 13 January 2021).

126. Aron, J.A.; Bulteel, A.J.; Clayman, K.A.; Cornett, J.A.; Filtz, K.; Heneghan, L.; Hubbell, K.T.; Huff, R.; Richter, A.J.; Yu, K.; et al. A Role for Telemedicine in Medical Education During the COVID-19 Pandemic. Acad. Med. 2020, 95, e4-e5. [CrossRef]

127. Vadukul, P.; Sharma, D.S.; Vincent, P. Massive pulmonary embolism following recovery from COVID-19 infection: Inflammation, thrombosis and the role of extended thromboprophylaxis. BMJ Case Rep. 2020, 13, e238168. [CrossRef]

128. Zhai, Z.; Li, C.; Chen, Y.; Gerotziafas, G.; Zhang, Z.; Wan, J.; Liu, P.; Elalamy, I.; Wang, C. Prevention Treatment of VTE Associated with COVID-19 Infection Consensus Statement Group. Prevention and Treatment of Venous Thromboembolism Associated with Coronavirus Disease 2019 Infection: A Consensus Statement before Guidelines. Thromb. Haemost. 2020, 120, 937-948. [CrossRef] [PubMed]

129. Patell, R.; Bogue, T.; Koshy, A.; Bindal, P.; Merrill, M.; Aird, W.C.; Bauer, K.A.; Zwicker, J.I. Post discharge thrombosis and hemorrhage in patients with COVID-19. Blood 2020, 136, 1342-1346. [CrossRef] [PubMed]

130. Mojoli, F.; Mongodi, S.; Orlando, A.; Arisi, E.; Pozzi, M.; Civardi, L.; Tavazzi, G.; Baldanti, F.; Bruno, R.; Iotti, G.A. COVID-19 Pavia Crisis Unit. Our recommendations for acute management of COVID-19. Crit. Care 2020, 8, 207. [CrossRef] [PubMed] 